\title{
Innovation and Productivity across Mexican Manufacturing Firms
}

\author{
Flor Brown',Alenka Guzmán²
}

\begin{abstract}
Following the Crépon-Duguet-Mairesse Model (1998), using a database with 2,078 Mexican manufacturing establishments from 2004 to 2006, adapting available proxy variables and proposing a different productivity estimation, this article sets out: Which is their innovation propensity? Which factors push on their innovation efforts? Are these efforts and the innovation favoring labor productivity? The main findings are: Mexican manufacturing establishments with a higher innovation propensity are the largest, with high technological intensity and market share. Advertising, knowledge appropriability, FDI, TT and access to credit have a positive effect on innovation efforts. Moreover, the innovation effort, together with export levels, FDI and access to technology have influenced the innovation of new processes and/or designs, particularly in local firms as compared to foreign firms. Finally, the variables: innovation, labour remunerations and capital intensity have a substantial effect on labor productivity and at a lower level market share, FDI and total quality control.
\end{abstract}

Keywords: technological efforts; innovation; productivity, cdm model; manufacturing industry; mexican firms

\footnotetext{
1,2 Universidad Nacional Autónoma de México, Av. Universidad No. 3000, Ciudad Universitaria, D. F. 045 I0, e-mail: brown@unam.mx. 2alenka.uami@gmail.com
} 


\section{Introduction}

This research paper has two goals: first, to study the determinants of innovation efforts of Mexican manufacturing establishments from 2004 to $2006^{4}$ and their impact on the development of new processes and products; and secondly, to determine how these efforts and innovation itself are affecting labor productivity, analyzing the differences among manufacturing industries.

The relationship between productivity and innovation has been a central theme of study for economists throughout various decades (Solow, 1957; Hall, Mairesse and Mohnen, 2010; Hall and Mairesse, 20II). At the level of firms, we would highlight the pioneer work conducted by Griliches (1964), who was faced with the difficulties of research and development (R\&D) capital specification to calculate the $R \& D$ firms' contribution to their productivity performance.

Based on methodological-theoretical proposals by Griliches (1980) and Pakes and Griliches (1984), toward the end of the 1990s, Crépon, Duguet and Mairesse (CDM) (1998) suggested a more complex method. The CDM model uses resource allocations intended for innovation activities and the outcomes of innovation processes in terms of productivity.Also, it allows for solving issues arising due to the presence of a certain relative selectivity toward innovation expenses, with the possible endogenous aspect of some independent variables and the qualitative nature presented in some of them.

CDM methodology has been used widely to analyze industrialized countries, ${ }^{5}$ and was recently applied to Latin American countries. ${ }^{6}$

\footnotetext{
${ }^{4}$ We only had access to aggregated statistics for establishments for this time period from three integrated data sources provided by INEGI and for the purpose of this study.

${ }^{5}$ Individual countries have been studied: Sweden (Janz, Lööf and Peters, 2004; Lööf and Heshmati, 2006); Canada (Therrien and Hanel, 2005); the Netherlands (Van Leeuwen and Klomp, 2006); France (Mairesse and Robin, 2009); Holland (Polder, Van Leeuwen, Mohnen and Raymond, 20I0). There are also comparative case studies that include Belgium, Denmark, Germany, Ireland, Italy, Holland and Norway (Mohnen, Mairesse and Dagenais, 2006); and France, Sweden, Finland, Holland, Denmark and China (Hall and Mairesse, 20II).

${ }^{6}$ Chile, Argentina, Uruguay and Costa Rica (Benavente, 2006; Alvarez, Bravo-Ortega and Navarro, 20I I;Arza and López, 20l0; Cassoni and Ramada, 2010; Monge-González and Hewitt, 2010). There is a comparative study concerning Argentina, Chile, Colombia, Costa Rica, Panama and Uruguay (Crespi and Zuñiga, 2012). There is also a study that compares European and Latin American countries, specifically Spain, France, Switzerland, Argentina, Brazil and Mexico (Raffo, Lhuillery and Miotti, 2008).
}

The studies based on CDM models estimate in general the first two equations with Heckman's methodology. But, unlike most of them that are proposing two independent equations for the knowledge and the productivity functions, we estimated these last two equations with a treatment effect model. In other words, we estimated the productivity equation including both types of firms: the innovative and the non innovative, while controlling for selection bias induced by the treatment assignment.

This research study questions some central matters related to the CDM model in order to analyze Mexico's manufacturing industry: What is the propensity toward innovation in Mexican manufacturing companies? What is the determining factor related to the innovation efforts in manufacturing companies? Do higher innovation efforts have a stronger labor productivity impact on companies? Are there differences among the firms in Mexico's manufacturing industries?

In this research paper, unlike the study conducted by Raffo, et al. (2008), the establishments in Mexico's manufacturing industry from 2004 to 2006 analysis incorporate additional variables to the database. Specifically, these variables are patents and trademarks as a proxy of innovations' appropriability, and remunerations as a proxy of human capital.

The research hypothesis states that Mexican companies with the highest propensity to innovation are the largest, and those with appropriability of their inventions, export activities and the largest market share. Nevertheless, when the time comes for a firm to take action in order to apply an amount of innovation-related expenditures, the importance of access to credit, technology transfer (TT), foreign direct investment, cooperation between companies, exportations and appropriability of knowledge becomes clear. Such innovation efforts, combined with exports, the size of the establishment and foreign direct investment, translate into new products and/or designs. Finally, innovation as an input, together with human capital, capital intensity per worker, foreign direct investment, establishment size and market share will tend to impact labor productivity in Mexico's manufacturing industry. Finally, the assumption is that industries with the highest technological intensity will have better conditions within this innovation and productivity scheme.

This paper is divided into four sections. In the second section we will specify and develop the CDM model in the case of Mexican manufacturing firms. In the third section we will analyze our research results vis a vis other similar studies that have been conducted in Latin American countries. And lastly, we will present our main conclusions. 


\section{Applying the CDM model to firms in Mexico's manufacturing industry: 2004-2006}

The structural changes started up in Mexico from the middle of the $80 \mathrm{~s}$ and the early $90 \mathrm{~s}$, also the incorporation to the North America Trade Agreement (NAFTA) open great expectations for a growing and competitive manufacturing sector that could led to a high economic growth, as the East Asian countries experience showed. However, the industrial production chains have been broken or weakened and the internal industrial demand have not reached the same growth dynamic (Brown \& Domínguez, 2013).

On the NAFTA agreement framework, we identify two periods of performance in the whole Mexican manufacturing sector.The manufacturing sector has grown from the middle of the nineties to $2000^{7}$, nevertheless in terms of TFP, based on Malquimist index estimation, the performance from 1994-2002 was quite poor (I.07\%) (lbid.). ${ }^{8}$

The growth dynamic has slow down from the beginning of the XXI century to the end of this decade. Indeed, the PTF in the whole manufacturing industry was worst from 2007 to 2009 (-2.0\%), with different performance across the manufacturing industries. ${ }^{9}$

This poor an erratic performance in the TFP in the Mexican manufacturing, set out the need to identify the factors behind the decision of firms to invest in technological efforts, and how this efforts can be traduced in innovation and finally how both explain the productivity performance. The results of this research could be useful to suggest an industrial policy, which foster an innovation virtuous circle spurring positive effects on labor productivity and finally improving the competitiveness of the manufacturing sector.

\section{Data}

The information used stems from the matching of three data sources: the Annual Industrial Survey (EIA, Encuesta Industrial Anual, 2004, 2005 and 2006), National Employment, Wages, Technology and Training Survey (ENESTYC, Encuesta Nacional de Empleo Salarios Tecnología y Capacitación) 2005 and the Industrial Census (Censo Industrial) 2005, entirely built-in by the National Institute of Statistics and Geography (INEGI, Instituto Nacional de Estadística y Geografía).

The EIA includes economic activity data from manufacturing establishments, their earnings, expenditures, employment and investment in physical acquisitions. The ENESTYC contains information on production organization and on the innovation activities of 8,000 establishments in the manufacturing sector. Finally, the Industrial Census includes four million establishments in the manufacturing sector, in trading and services. There are common variables among the three surveys, but some only appear in one of them, such as the case of trademarks and patents (Census, 2005). The EIA has no information regarding innovative activities and the ENESTYC does not include production data. In order to build a database that includes adequate variables for the CDM model, we used the three sources of information in a complementary manner. In addition, not all establishments are considered in those three sources of information. For that reason the sample of establishments in this research was reduced to $2,078 .{ }^{10}$ We used this establishment sample for each year from 2004 to 2006.

Because the sample was defined at the level of establishments, not at the level of firms, this could create some biased results. Some variables may be underestimated when, for example, one establishment in the corporate reports innovation activity that is not reported by the other establishments in the corporate.

\section{Estimation methodology}

The CDM model is expressed in four equations: (I) the company's decision to take part in investments in R\&D; (2) the intensity with which the company is committed to innovate, i.e., R\&D or other types of innovation efforts; (3) the function of knowledge production that links R\&D intensity with innovation; (4) and the productivity function when innovation is an input."

\footnotetext{
${ }^{7}$ According to Annual Industry Survey -EIA-(INEGI From 1995 to 2000, the average annual rate of the whole Mexican manufacturing sector was 1.9 percent. From 2003 to 2009 the annual rate was 1.62 percent.

${ }^{8}$ Especially in transport equipment and non electric machinery. Unlike some industries have shown a positive PTF (motor vehicles, non-metallic product, rubber \& plastic products).

9 Only four industries have shown a positive PTF (motor vehicles -2\%-, transport equipment $-1-9 \%$, beverage and tobacco $-0.4 \%$ - and chemical $-0.4 \%$ - The technical change index was positive for 12 industries but only there were three of them increased the net efficiency (other industries, motor vehicles wood and their products). The technical change index was positive for 12 industries but only there were three of them increased the net efficiency (other industries, motor vehicles wood and their products). Not even if there were introduced new technologies foster by the NAFTA, not many firms of each industry were close to the technological frontier (lbid.).

${ }^{10}$ We did not include establishments with a number of employees under 50 , as their information is not reliable.

"We differ from other CDM models on the usage of dependent and independent variables across the equations, because of the information coming from different surveys.
} 
The four equations were organized in two levels. In the first level we estimated two equations using the Heckman methodology: propensity to innovate and innovation effort determinants. And in the second level we used two equations: knowledge function and labor productivity, using the endogenous treatment effects methodology.

\section{First-level model estimation}

In order to eliminate possible selection bias (Janz, et. al, 2004), both functions, Propensity to Innovate (dtec) and Innovation Effort (letec), were estimated simultaneously by using the two-step estimation method by Heckman (1979), with a probit specification for the first function (dtec) and a Tobit model (Amemiya, 1984) for the second (letec). Considering that we used a pool-type estimate, constants $\left(\beta_{0}, \alpha_{0}\right)$ are equal among the cross-section elements of each of the two equations. At this point in the step, we obtained the innovation effort prediction ie $\mathrm{l}_{\mathrm{i}, \mathrm{t}}$ and the inverse Mills ratio $\left(\lambda_{\mathrm{it}}\right)$, which will be used in the following equation.

Equation I: Propensity to Innovate (dtec)

$\operatorname{detec}_{i, t}=\beta_{0}+X_{1, i, t} \beta_{1}+\varepsilon_{1, i t}$

where: $i=1,2,,,, 2074$ establishments and $t=1,, 3$ year

$X_{1, i, t}=$ exports, size, market, divinova and $\varepsilon_{1, i t}$ the error term

With this equation we want to determine the possible effect of factors on the propensity of companies to innovate. In the absence of data on R\&D expenses, we decided to use payments made by companies to acquire technology as an approximation (Boyer and Didier, 1998). ${ }^{12}$ The following is a function we are establishing in order to estimate:

Where:

I. The dependent variable (dtec) is binary; it is equal to one $(\mathrm{I})$ if the establishment invested in technology and it is zero if it did not.

2. exp:is thepercentage of exportsin theestablishment's total sales. With this variable we attempt to estimate the positive effect expected from exports on innovation, as a result of competition and learning processes in companies. Firms oriented toward global markets have a higher probability of introducing new products when compared to local marketintended production, due to the greater competition confronted in international markets (Janz, et. al, 2004).

3. size3: is a binary variable equal to one (I) for large companies with more than 500 employees. The existence of a positive correlation between size and innovation is indicated in the literature (Acs \& Audretsch, 1988). However, in some cases the correlation might not be linear. For example, Kamien and Schwartz (1982) found a U-shaped non-linear correlation between the intensity of innovation and the size of companies.

4. market: is the establishment's participation in its industrial branch activities. It is considered as a proxy variable of innovation success. Considering that companies' success is a result of innovation, it secures increased market participation, either through access to new market niches or through the incorporation of new clients (Therrien and Hanel, 2005). In that sense we expect a positive correlation associated with the decision to invest in innovation.

5. divinnov: innovative industries. This is a dummy variable for industrial divisions we identified as "innovative," i.e., those with higher innovation expenditures than the industrial average (chemical industry, metal products, machinery and equipment, and other manufacturing industries).

Equation 2: Innovation Effort (letec) Determinants

$$
\begin{aligned}
& \text { letec }_{i, t}=\alpha_{0}+X_{2, i t} \alpha_{1}+\varepsilon_{2, i t} \\
& \text { Where: } \\
& X_{2, i t}=\text { advertising, P\&T, Foreing Direct Investment, } \\
& \text { exports, market, collaboration, technology transfer, } \\
& \text { access to credit, year2004, year2005 } \\
& \varepsilon_{2, i t}=\text { is the error term }
\end{aligned}
$$

After a company decides to innovate, it establishes the amount of resources it can allocate to innovation. In this equation, we intend to estimate the amount of investment in innovation determined by macroeconomic conditions, market structure and the company's features. Henceforth, the following equation is formulated:

\section{Where:}

I. letec: technology expenditures on logarithms. This represents our dependent variable. It includes all expenditures involved in innovation efforts made by companies, even if they are not reported as R\&D spending. The fact that we do not have data for R\&D expenditures has led us to consider the establishment's technological purchases and transfer expenditures as a proxy variable.

\footnotetext{
12 A company's efforts to assimilate and innovate a technology are associated with their R\&D expenditures. However, they are also linked to the knowledge deployed in the same productive process, when trying to improve productive operations. According to Boyer and Didier (1998), expenditures not linked to R\&D make up a considerable part of total innovation expenditures in almost every industrial sector, including cutting-edge industrial sectors.
} 
2. adv: advertising expenditures. This is a logarithm of the company's expenditures on advertising. With this variable we are looking to estimate the positive effect that innovation has on the company's efforts to gain clients and increase their market share (Askenazy, et al., 20l0).

3. p\&t: patents and trademarks. This is a binary variable equal to one $(I)$ if the establishment has intellectual property rights, having registered a brand, a patent or both. Companies use different strategies to innovate and develop new products, which are protected via patents or trademark registration in order to differentiate their products (Archibugi and Pianta, 1996; Mendonça et al., 2004). This variable enables us to analyze the importance it has been given in literature, regarding its appropriability-related innovation activities (Arrow, 1962).

4. dfi: direct foreign investment. This is a binary variable equal to one ( $\mathrm{I}$ ) when the establishment has an equity stake of more than $25 \%$ coming from foreign investment and zero (0) if it does not. There is no consensus when it comes to the effect that foreign investment has on innovation. On the one hand, some authors find that transnational companies have more technological sophistication, easier access to financing and also have access to skilled human capital, thus recording a positive effect on innovation (Girma and Gorg, 2007; Kumar and Aggarwal, 2005). However, other authors do not confirm these findings (Dussel, et al., 2003).

5. exp: is the percentage of exports in the establishment's total sales.

6. market: is the establishment's participation in its industrial branch activities. It is considered as a proxy variable of innovation success.

7. coop: cooperation. The effect of cooperation among companies is still unclear in relation to innovation. R\&D cooperation among firms, on the one hand, is beneficial to the growth of a knowledge legacy that becomes available in companies, inasmuch as a technological knowledge spillage occurs, and therefore, a decrease in production costs. However, on the other hand, it contributes to an internal R\&D decrease due to the weak appropriability of returns coming from innovation (Kamien and Swartz,

\footnotetext{
${ }^{13}$ Patents are indicators of innovation and intellectual property protection (Griliches and Mairesse, 1984). Some authors (Mendonça et al, 2004; Rogers, Helmers and Greenhalgh, 2007) identify the importance of using registrations of their trademarks as a proxy. If we assume that under product differentiation there is an innovation effort on the company's behalf, then we can justify the use of this variable.
}

1982; De Bondt, 1997). Since we do not have information on different forms of collaboration among firms, we will use the collaboration among firms in the corporations as a proxy, while under the assumption that information and cooperation are typical in this form of organization.

8. TT: technology transfer. This is linked to the learning and development effect of technological abilities (Katrack, 1997; Johnson, 2002). An incoming and outgoing technological spillover occurs during this interactive process. The complementarity between R\&D and external technological purchase must, in theory, generate a virtuous circle for companies. On the one hand, an internal R\&D ability may favor external knowledge absorption (Cohen and Levinthal, 1989; Kamien and Zang, 2000), and furthermore, it may enable the adoption of imported technologies into local markets (Katrak, 1997; Arora, 2009). On the other hand, acquiring external technologies may contribute to an optimization of the company's R\&D efforts, and therefore, an increase in its technological abilities, and eventually, its endogenous innovation (Kaiser, 2002).

9. acredit: access to financing to companies. Credit is crucial for financing innovation activities. Several studies show the specific importance that public financing has on innovation activities in Latin American companies (Navarro et al.2010). However, we did not have information related to public financing. Our information is only associated with the establishments that have access to credit. Our assumption is that these establishments are those with available resources for innovation.

\section{0. year04: year 2004.}

II. year05: year 2005.

\section{Second-level model estimation}

In this stage, with the intention of eliminating the possible selection and endogeneity biases, we estimated the knowledge production and productivity functions together. We used the methodology from what is known as the endogenous treatment effects models (Heckman, 1976 and 1978; Cameron and Trivedi, 2005; Wooldridge, 2010). With this methodology, we specified the knowledge production function (procdes) as an endogenous treatment equation, which is explained by the latent innovation effort (letec $\left.{ }_{i, t}^{*}\right)$, having previously estimated the inverse Mills ratio and other inputs $\left(\mathrm{W}_{\mathrm{i}, \mathrm{t}}\right)$. 


\section{Equation 3: Function of Knowledge Production (procdes)}

Once companies have decided to spend on innovation, it is wise to seek how such effort translates into the development of new processes and products, by means of a knowledge function expressed in the equation that estimates the input of innovation that will affect productivity: ${ }^{14}$ The equation suggested here is the following:

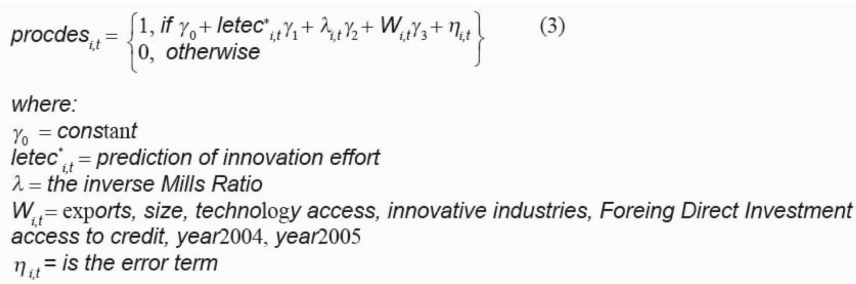

Where:

I. procdes: process and design. It represents the success from innovation efforts and is the dependent variable; with one for companies presenting changes in their production and/or design processes and is estimated in only one equation. ${ }^{15}$ This indicator's relevance is justified by the elevated "co-linearity" between design and product innovations presented by the establishments in the sample, i.e., establishments carrying out processes innovations are the same as those that will carry out design innovations. In addition to the previously defined independent $\mathrm{v}$ ariables, we will add:

2. iel: the estimated level of expenditures on innovation from the two previous equations for all companies.

3. pmills: the inverse Mills ratio. It will allow us to correct possible selection bias.

4. size: the establishment's size. This is a dummy variable with one for small, two for medium-sized and three for large establishments.

5. daccesotec: technology access.

6. divinnov: innovative industries.

7. dfi: direct foreign investment.

14 Knowledge progress indicators (Pakes and Griliches, 1984:58) were estimated on the basis of a patent equation that links past research to the logarithmic increase of current knowledge and its link to patents. The knowledge progress indicator shows that patents are a good indicator of existing differences among firms regarding knowledge breakthrough.

\section{Equation 4: Productivity (lpt) Determinants ${ }^{16}$}

Finally, we will analyze the effect that innovation has on labor productivity. We used a Cobb Douglas production function with constant returns to scale. We included capital, labor, the "innovation input" variable (equation 3) and other factors associated with labor productivity such, as reengineering, quality controls, market share and direct foreign investment:

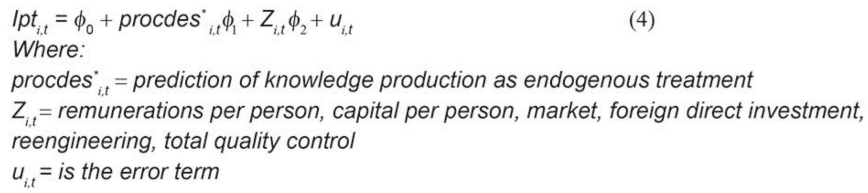

Where:

I. Ipt: labor productivity in logarithms.

2. le2: prediction of innovation input, resulting from the function of knowledge.

3. K: fixed capital per person or intensity of capital per person. This is the variable typically used in Cobb Douglas functions.

4. remun: remunerations per person. We use this variable, together with reengineering and total quality control, as an estimate for human capital. Knowledge absorption ability is linked to the establishment's effort to introduce total quality control. The higher the skills and competence, the better the staff's remuneration (Mulligan and Sala-i-Martin, $1995^{17}$ ).

5. reengi: reengineering. This variable refers to a knowledge absorption ability that could have possible impacts on labor productivity. It is a binary variable with one (I) for the establishments that made changes in their productive processes.

\footnotetext{
${ }^{15}$ As suggested by Crespi \& Zúñiga (20I2), a technological innovation indicator was built and includes product and process innovations.

${ }^{16}$ The productivity equation is the second equation in the system. Its determinants are the result of the existence of endogenous treatment, as defined by the knowledge production function, and the set of other variables.

17 Mulligan and Sala-i-Martin (1995) define added human capital as the sum of abilities subjected to the individual labor force and present capital stock by using individual earnings.
} 
6. tqc: total quality control. This is a binary variable with one (I) for the establishments that have introduced total quality control in their productive processes requiring skilled labor workers.

7. market: the establishment's participation in its industrial branch activities.

8. dfi: direct foreign investment.

From an analytical point of view, the parameter $\phi_{1}$ represents the average treatment effect (ATE) that measures the average productivity differential among the companies that innovate versus those that do not innovate, in accordance with the estimate calculated in the knowledge production function.

\section{Innovation effort analysis, innovation and productivity in manufacturing companies in Mexico}

\section{Statistical evidence}

Among the 2,078 establishments sampled, $40 \%$ are large companies with more than 250 employees, $45 \%$ are mediumsized companies (from I0I to 249 employees) and only $15 \%$ are small-sized companies (from 50 to 100 employees) (see Table I).

As found in other Latin American countries, innovation is only carried out in a small number of companies. Out of the total number of sampled establishments, only 349 (17\%) registered innovation expenditures. These are the establishments we refer to as innovators, and the others, non-innovators $(73 \%)$. Most establishments are essentially large and very large, as in the case of the Latin American manufacturing sector (see footnote 12).

Of all the innovator establishments, close to half have foreign equity participation (47\%), while only $19 \%$ of the non-innovator establishments have foreign participation.

The Industrial Census provides patent and brand information that allows us to build a combined index that constitutes the proxy variable of innovation. Table I depicts how $37 \%$ out of the total sampled establishments registered either a trademark or patent. More than half of the establishments with trademarks or patents correspond to innovators and just over a third to non-innovators. For non-innovators, trademarks carry a greater weight.

The weak collaboration among companies in our sample is presented in Table I. Indeed, only 14\% of establishments performed collaboration activities in their corporate. As in the previous case, the percentage is higher among innovator establishments than among non-innovator establishments (24\% and I $2 \%$, respectively).
Variables accounting for the largest market share in our study are: exports, the establishment's sales participation in its industrial segment and advertising expenditures. Statistics from the sampled establishments confirm that innovators have a stronger presence in the market. Innovators export $19 \%$ of their sales, in comparison to $13 \%$ for non-innovators; they contribute $7.3 \%$ of the sales in their industrial segment, which contrasts with $4.9 \%$ in the case of non-innovators. They also report the highest expenditures in advertising per person $(\$ 145,000$ per year on average, compared to $\$ 2,000)$. We also note that among our sampled innovator and noninnovator establishments we could not detect important differences in access to credit. On average, $80 \%$ of the establishments have access to credit.

Of the total sample, $54 \%$ registered design and/or process innovations. In particular, innovator establishments reported a higher percentage compared to the average (64\%). Process reengineering and total quality control are fairly widespread processes among companies. Human capital could have an influence on innovation inasmuch as it represents knowledge and experience. The information we provide does not reflect large differences among establishments, which would suggest standardization in the use of these processes (see Table I).

Innovator establishments are linked to higher levels of productivity, remunerations and capital assets. Indeed, remunerations at innovator establishments average $\$ 3,680$ per person per month; interestingly enough, remunerations for non-innovators average $\$ 2,550$ per person per month.Additionally, capital intensity per person is notoriously higher at innovator establishments (almost twice as high). And there is an eight-fold productivity level in innovator establishments in comparison with non-innovator establishments. 


\begin{tabular}{|c|c|c|c|c|c|c|}
\hline \multicolumn{7}{|l|}{ Establishments } \\
\hline & Total & & Innovators & & $\begin{array}{l}\text { Non-innova- } \\
\text { tors }\end{array}$ & \\
\hline & Number & $\%$ & Number & $\%$ & Number & $\%$ \\
\hline Size & 2078 & 100 & 349 & 100 & 1729 & 100 \\
\hline Small & 309 & 15 & 51 & 15 & 258 & 15 \\
\hline Medium & 942 & 45 & 90 & 26 & 852 & 49 \\
\hline Large & 464 & 22 & 101 & 29 & 363 & 21 \\
\hline Very large & 363 & 18 & 107 & 31 & 256 & 15 \\
\hline Foreign direct investment & 500 & 24 & 164 & 47 & 336 & 19 \\
\hline Patents and trademarks & 779 & 37 & 188 & 54 & 591 & 34 \\
\hline Collaboration & 285 & 14 & 85 & 24 & 200 & 12 \\
\hline TT & 160 & 8 & 57 & 16 & 103 & 6 \\
\hline Credit access & 1703 & 82 & 276 & 79 & 1427 & 83 \\
\hline Innovation expenditures & 349 & 17 & & & & \\
\hline Design and/or process innovations & 1127 & 54 & 218 & 63 & 909 & 53 \\
\hline Process reengineering & 734 & 35 & 129 & 37 & 605 & 35 \\
\hline Quality control & 1185 & 57 & 194 & 56 & 991 & 57 \\
\hline \multicolumn{7}{|l|}{ Average 2004-2006 } \\
\hline Exports/Total sales & 6234 & 14.5 & 1047 & 19 & 5187 & 13 \\
\hline Standard error & & 25.87 & & 26.74 & & 25.6 \\
\hline Market & 6234 & 5.5 & 1047 & 7.3 & 5187 & 4.9 \\
\hline Standard error & & 10.51 & & 12.85 & & 9.91 \\
\hline Advertising per person* & 6234 & 25600 & 1047 & 145000 & 5187 & 2000 \\
\hline Standard error & & 1191.9 & & 2949 & & 19 \\
\hline Remuneration per person* & 6234 & 2740 & 1047 & 3680 & 5187 & 2550 \\
\hline Standard error & & 32.8 & & 60.6 & & 23 \\
\hline Capital per person* & 6234 & 5252 & 1047 & 8400 & 5187 & 4618 \\
\hline Standard error & & 4063.8 & & 7677.3 & & 2819 \\
\hline Labor productivity* & & 3000 & & 11030 & & I 440 \\
\hline Standard error & & 7119 & & 17399 & & 1198 \\
\hline
\end{tabular}

Table I: Characteristics of Mexican manufacturing establishments, 2004-2006. 2003 Mx pesos. Source: based on EIA (2004, 2005 and 2006), ENESTYC (2005) and Industrial Census (2005).

ISSN: 07 I8-2724. (http://www.jotmi.org) 
When analyzing innovator establishments per manufacturing divisions, we identify four main categories: Chemical and chemical products industry; Metal products, machinery and equipment; Other manufacturing industries; and at a smaller scale, Food, beverage and tobacco. Within these four industrial divisions, we find approximately four-fifths of the innovator establishments in our sample. Innovator establishments from these industries are essentially large and very large; between half and three-fifths of these establishments can be found within these size categories.

The innovative profile of establishments is confirmed in the aforementioned four industrial divisions. Thus, as seen in Figure I, variables associated with innovation are present and addressed in a substantive manner in these industries, in comparison with others. The number of establishments that focus their efforts on innovation expenditures and total product quality is especially noteworthy.
This effort is linked to the export-related orientation of such industries, particularly in the division of metal products, machinery and equipment, and also found in the automotive, auto parts and electrical, electronics and components industries. At a smaller scale we find this in the chemical industry. Additionally, advertising has a relevant role in the chemical industry, and we also find that remunerations, capital intensity per worker and labor productivity are notoriously higher in this industry.

The foregoing corroborates the results from other studies (Guzmán, López and Venegas, 2012) in the sense that mature technology sectors carry more weight in Mexico's productive specialization. Moreover, scarce innovation in the country is focused in other industrial sectors, as seen in Figure $\mathrm{I}$.

\section{Mexican manufacturing establishments with variables asociated to innovation, 2004-2006 (number)}

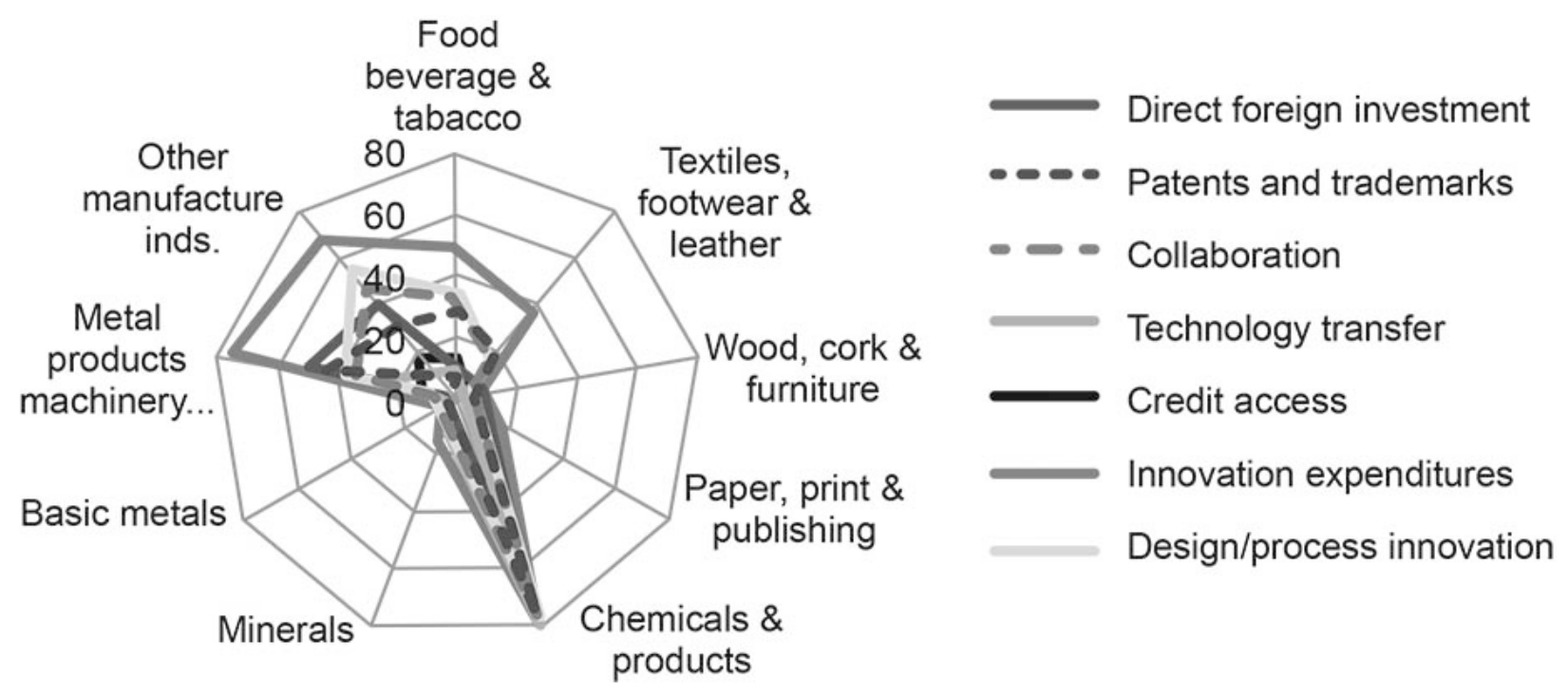

Figure I. Source: own elaboration based on EIA (2004, 2005 and 2006), ENESTYC (2005) and Industrial Census (2005). 


\section{Innovation and Labor Productivity: Result Analysis}

Equation I: Propensity to Innovate

Results obtained in Equation I demonstrate that Mexican companies with higher propensity to innovate are the largest, confirming the Schumpeterian hypothesis on the size of the firm as a determinant variable of innovation.

Market share is statistically significant in relation to the probability to innovate. In the case of exports, our results point to the opposite direction as studies in which they are highly associated with the companies' decision to innovate. When we identified the impact of the innovative industrial divisions on the establishments' propensity to innovate, we found it to be statistically significant. This confirms the assumption that industries with the highest technological intensity will have better conditions within this innovation and productivity scheme.

\section{Equation 2: Innovation Effort Determinants}

Exports and cooperation among companies were not statistically significant. On the other hand, we found advertising, market, knowledge appropriability, foreign direct investment, TT and access to credit to have a positive effect on innovation efforts.

As for direct foreign investment (DFI), its elasticity is particularly noteworthy: with a $10 \%$ increase in DFI, investment in innovation rises by $15 \%$ (Table 2). Foreign companies have more resources to invest in innovation, in comparison to other firms. Expenditures on innovation by foreign companies are sometimes linked to product adaptation for domestic or export markets. In other situations, they are related to R\&D global relocation to countries with elevated human capital and substantially lower wages (as in the case of India). ${ }^{18}$

\footnotetext{
${ }_{18}$ Companies may also decide to not assign investment expenditures to innovation, since they view the recipient country as lacking in the technological abilities for performing such activities. Different strategies implemented by multinational companies are mirrored in the mixed results obtained from different studies. Specifically, the effect is positive in the case of Argentina, Colombia and Panama (Crespi and Zúñiga, 2012) and Chile (Benavente, 2006), but non-significant for Chile, Colombia and Costa Rica (Crespi and Zuñiga, 20I2), as well as negative in the case of Uruguay (Cassoni and Ramada, 2010).
}

Furthermore, elasticity is strong when it comes to appropriability: a $10 \%$ growth in trademark or patent registrations by the establishments increases expenditures on innovation by $6.6 \%$. Such a result is consistent with theoretical literature suggesting that companies will only begin to invest in innovation after they have protected their inventions, and consequently, can secure a return on their R\&D (Scherer, 2005). ${ }^{19}$ The elasticity of TT is also high: a $10 \%$ rise in TT increases innovation expenditures by $11.1 \%$. It is widely recognized that a firm's TT allows access to leading edge technology and this improves processes and stimulates R\&D efforts (Arora, 2009). This does not occur, however, in countries with a weak environment for inventive activity (Zúñiga, Guzmán and Brown, 2007).

A $10 \%$ increase in access to credit expands expenditures by $4 \%{ }^{20}$ The aforementioned results from banks' preference to grant loans for purchasing machinery, as they embody a guarantee, while this is hardly the case with other types of loans.

Finally, market share and advertising have a smaller impact. A $10 \%$ increase in each of these variables elevates innovation expenditures by only $1 \%$ and $0.8 \%$, respectively. ${ }^{21}$

\footnotetext{
${ }^{19}$ Accordingly, Benavente (2006) and Crespi and Zuñiga (2012) obtained a positive coefficient for Chile. Nevertheless, Alvarez, Bravo-Ortega and Navarro (20II) found an effect that was statistically non-significant for the same country. In industrialized countries, the results are also mixed. In Germany the coefficient is negative and in Sweden it is positive (Loof and Heshmati, 2006).

${ }^{20}$ Case studies in Chile (Alvarez, Bravo-Ortega and Navarro, 20II) and Uruguay (Cassoni and Ramada, 2010) indicate that access to credit increases the intensity of investment in embodied technologies but not in other activities.

${ }^{21}$ The importance of these variables is reflected in case studies in Canada (Therrien and Hanel, 2005), Germany and Sweden (Loof and Heshmati, 2006) and Chile (Benavente, 2006).
} 


\begin{tabular}{|l|l|l|l|}
\hline & Coef. & $\mathrm{P}>\mathrm{z}$ & \\
\hline \% of exports in the establishment's total sales & 0.001 & 0.23 & \\
\hline Innovative Industries & 0.275 & 0.00 & \\
\hline large companies comprising more than 500 employees & 0.436 & 0.00 & \\
\hline \% of the establishment in its industrial branch activities & 0.006 & 0.00 & \\
\hline Year & 0.000 & 0.880 & Elasticities \\
\hline Constant & -1.269 & 0.000 & 0.08 \\
\hline Innovation Effort Determinantes (Letec) & \multicolumn{1}{|c|}{ Coef } & P>z & 0.00 \\
\hline Advertising & 0.085 & 0.000 & 0.10 \\
\hline \% of exports in the establishment's total sales & -0.004 & 0.163 & 0.66 \\
\hline \% of the establishment in its industrial branch activities & 0.017 & 0.003 & 1.50 \\
\hline patents and trademarks & 0.515 & 0.000 & 0.00 \\
\hline Foreign Direct Investment & 0.924 & 0.000 & $\mathrm{I}$ \\
\hline Collaboration & -0.045 & 0.729 & 0.40 \\
\hline TT & 0.757 & 0.000 & 0.00 \\
\hline Access to Financing to Companies & 0.347 & 0.019 & 0.00 \\
\hline year 2004 & 0.028 & 0.86 & \\
\hline year 2005 & 0.063 & 0.44 & 0.000 \\
\hline Constant & 8.143 & & \\
\hline
\end{tabular}

Table 2. Results from propensity to innovate and innovation effort determinants equations. (Heckman Methodology: Panel pool in two steps)

Wald test of indep. eqns. $($ rho $=0): \operatorname{chi} 2(I)=70.33$ Prob $>$ chi2 $=0.0000$

Source: own elaboration based on EIA (2004, 2005 and 2006), ENESTYC (2005) and Industrial Census (2005).

ISSN: 07 I8-2724. (http://www.jotmi.org) 
Equation 3: Function of Knowledge Production

As previously explained, the function of knowledge production allows us to estimate the effect on the amount of innovation expenditures made by companies in their production or design processes--an innovation input to be used in the productivity function. However, interpreting the regression coefficients of this selection equation is complicated, because the observed dependent variable (y) can be expressed through only two values ( 0 vs. I), and the estimation process uses the probability of $y=1 .{ }^{22}$ For this reason we only refer to the sign of the coefficients and its significance, in order to consider their impact on the innovation process.

The innovation effort variable estimated in equation 2 turned out to be statistically significant in product process and/or design innovation with a magnitude of $0.4 \mathrm{I}$ (see Table 3 ). Even though there is certain consensus in various studies regarding a positive coefficient, this is not the case with regard to its magnitude (Crespi and Zúñiga, 2012; Cassoni and Ramada, 20I0).

Some authors, separately, study the effects of innovation efforts on product processes and design, by enhancing the evidence. In Chile, for example, research has identified a 0.002 coefficient result from the probability equation for product innovation and a $0.00 \mathrm{I}$ result in process innovation (Benavente, 2006). In a joint evaluation, on product process and/or design, Crespi and Zúñiga (2012) report a 1.18 coefficient in the same country. This coefficient is found to be higher in industrialized countries and only includes innovative companies (a 0.49 coefficient in Germany and Sweden, Loof and Heshmati, 2006).

Access to technologies has an important effect on innovation in process and/or design. Not every consulted study includes access to technology, however proxy variables are built. In Uruguay, technical assistance has been used, with an observed positive effect of 0.102 (Casoni and Ramada, 2010). ${ }^{23}$

Foreign direct investment has a negative effect on process and/or design innovation. This negative result coincides with the estimates for Chile and for Colombia, Panama,Argentina and Uruguay. The aforementioned might be explained by the fact that innovation is usually carried out by multinationals in their countries of origin or in other locations in industrialized countries. Within the open economies context, national

\footnotetext{
${ }^{22}$ (sagepub.com/upm-data/30234_Chapter4.pdf)

${ }^{23}$ In turn, a German and Swedish study uses access to science and technology on behalf of companies, finding a positive effect $(0.27)$ and a negative effect $(-0.68)$, respectively (Loof and Heshmati, 2006).
}

companies are making an effort to improve processes and products to maintain competitiveness (Brown and Minian, 1998). To the contrary, in the Argentinean and Uruguayan manufacturing industries, studies show a positive coefficient (Arza and Lopez, 20I0; Cassoni and Ramada, 2010). This evidence suggests that national companies have a higher probability of carrying out process and/or design innovations. The size of the establishment is not statically significant in contrast with the studies in Chile, Argentina, Colombia, Panama, Costa Rica, Colombia and Uruguay. Nevertheless, size may or may not be of importance according to the type of industry and market dynamism in the observed industrial segment (Malerba and Orsenigo, 1997).

Finally, export participation increases the chances to innovate in design and products in Mexican manufacturing establishments. This result is in line with the Chilean and Argentinean studies.A larger magnitude effect can be seen in Costa Rica and Uruguay. These results contrast with those in Colombia, where the effect is negative (Table 3). ${ }^{24}$

\section{Equation 4: Productivity Determinants}

According to our hypothesis, we can confirm the positive impact of an innovation input on labor productivity. We calculate the effect from innovation on labor productivity using two coefficients from the productivity function. The coefficient associated with the prediction for the innovation input, calculated in relation to the knowledge production function, corresponds to the "average treatment effect" (ATE). We can thus state that firms that innovate have a level of productivity that is 1.3 times higher than firms that do not innovate.

The second coefficient refers to the innovation effort calculated in the second equation. According to this coefficient, a $10 \%$ increase in this effort results in a $2.4 \%$ rise in labor productivity.

Compared to other studies carried out in Latin American countries, where the coefficient fluctuates from 0.1 to 1.92 (Cassoni and Ramada, 2010; Crespi and Zúñiga, 2012), the estimated coefficient in our research for Mexico is 0.14 .25

The contribution of the intensity of capital per worker to labor productivity is positive. The elasticity of the Mexican manufacturing industry in this case $(0.35)$ is lower in comparison to the case of Chile ( 0.7 elasticity). As for Chile (Benavente, 2006) and for France, Switzerland, Argentina,

\footnotetext{
${ }^{24}$ See: Benavente, 2006; Crespi and Zuñiga, 2012; Cassoni and Ramada, 2010.

${ }^{25}$ For the United States the elasticity reported by Griliches (I984) is 0.1 . By using a broader R\&D definition in other case studies, the range increases from 0.10 to 0.25 (Hall, Mairesse and Mohnen, 2010).
} 
Brazil and Mexico (Raffo et al., 2008), the importance of human capital was confirmed, remunerations per person and total quality control were statistically significant in relation to labor productivity with a high elasticity ( 0.56 and 0.1 I respectively).

As we expected we were able to confirm the Schumpeterian hypothesis regarding the correlation among large firms and productivity levels, the size of companies was statistically significant when innovation input was included in the productivity equation.
As for foreign capital, its positive effect on labor productivity has been proven, but it is significantly smaller. This result is probably related to the weak linkage between multinational and national companies in the Mexican manufacturing industry. In addition, it might also have something to do with a lack of technological and learning skills in national companies when interacting with foreign companies, by not taking advantage of technological knowledge spillovers.

Finally, we observe a positive relationship between the company's market share and labor productivity. In the presence of dynamic markets, which are characterized by the introduction of new products or as a result of new production processes, innovative companies will have an incentive to increase their participation. This factor will reinforce the company's decision to innovate, thus positively affecting labor productivity.

\begin{tabular}{|l|l|l|l|}
\hline Function of Knowledge Production (procdes) & \multicolumn{2}{|c|}{ Coef. } & \multicolumn{2}{|c|}{$\mathrm{P}>\mathrm{z}$} & \\
\hline $\begin{array}{l}\lambda \\
\text { Prediction value of innovation effort }\end{array}$ & 0.365 & 0.0 & \\
\hline Mills inverse ratio & -0.024 & 0.89 & \\
\hline \% of exports in the establishment's total sales & 0.003 & 0.0 & \\
\hline Size & $0.14 \mathrm{I}$ & 0.0 & \\
\hline Technology access & 0.206 & 0.0 & \\
\hline Innovative Industries & 0.069 & 0.17 & \\
\hline Foreign Direct Investment & -0.341 & 0.0 & \\
\hline Constant & -3.758 & 0.0 & \\
\hline Productivity Determinants (Produc) & Coef & $\mathrm{P}>\mathrm{z}$ & Elasticities \\
\hline Remunerations per person & 0.564 & 0.00 & 0.57 \\
\hline fixed capital per person & 0.356 & 0.00 & 0.35 \\
\hline \% of the establishment in its industrial branch activities & 0.026 & 0.00 & 0.16 \\
\hline Foreign Direct Investment & 0.002 & 0.00 & 0.04 \\
\hline Pmills & -0.065 & 0.48 & \\
\hline Reengineering & -0.034 & 0.28 & 0.00 \\
\hline Total Quality Control & 0.106 & 0.00 & 0.1 I \\
\hline Predicion of knowledge production & 1.248 & 0.00 & \\
\hline Prediction value of innovation effort & 0.139 & 0.00 & 2.48 \\
\hline Constant & 1.749 & 0.00 & \\
\hline & & & \\
\hline
\end{tabular}

Table 3: Results from Function of Knowledge Production and Productivity Determinants (Endogenous treatment effects methodology: Panel pool) Source: own elaboration based on EIA (2004, 2005 and 2006), ENESTYC (2005) and Industrial Census (2005).

ISSN: 07I 8-2724. (http://www.jotmi.org) 


\section{Conclusions}

Our results prove that, in order to analyze the effect from innovation on productivity, it is necessary to consider every element of the process: the innovation effort, which can turn out to be successful or not; invention and its appropriability; the introduction of innovation in production processes and/ or markets, through new designs (products); and finally, the effects on productivity.

We were able to confirm the hypothesis that Mexican companies with more propensity to innovate are the large companies and those belonging to industries with high technological intensity. In addition exports and market share are also important in the probability to innovate. When a company implements the decision to make innovation expenditures, it is important to have access to: credit, technological transfer, foreign direct investment and knowledge appropriability. However, cooperation among companies, size of the establishment and exports were not found to be significant. These results point to the need to create an industrial policy that will contribute to eliminating obstacles faced by companies in access to new technologies (TT, TT) and/or credit. They also highlight the relevance of having a strong intellectual protection system that will guarantee entrepreneurs a return on their innovation investments. The evidence suggests the need to promote a culture of cooperation among companies, and from companies to universities and development centers. To summarize, we observe a need to create public policies that motivate and boost innovation efforts.

With regard to the knowledge function, we discovered that effort in innovation, resulting from the first two equations of the model, and added to exports and the size of establishments, determined innovation resulting in new processes and/or designs. As opposed to what we had anticipated, we were able to identify national firms with stronger product and/or design innovation, in comparison to foreign firms.

As a result of our study, we can see the unquestionable importance of industrial policies recognizing disparities in technological skills and the complex relationship existing between national and foreign companies, as well as working toward a better insertion of local companies into industrial linkages. To the extent that national companies dedicate more efforts to innovation, and are capable of absorbing external and border technologies, we will see positive effects on innovation, and accordingly, on labor productivity. Finally, on the one hand, we confirm the relative hypothesis that an innovation input added to fixed capital per person may have a substantial impact on labor productivity. The establishments that invest in capital have skilled workers capable of taking advantage of capital-embodied knowledge and therefore more probability to innovate. Our proxies of human capital, such as remunerations per person and reengineering, were statistically significant and therefore confirm the effect of these variables in productivity. The market share also makes a contribution to labor productivity, although less than capital per person. Even less was the impact from direct foreign investment, although it was positive.

One of the limitations of this research is the fact that we did not have an innovation survey at the level of establishments that would have included variables such as R\&D, human capital, cooperation among companies and universities, and support and/or public subsidies for companies. Another limitation was not being able to expand the sample or the research time period.

The use of proxy variables may have affected the estimates, in terms of the magnitude and the coefficient signs in different equations. The fact that countries do not have homogenous information makes it difficult to make comparisons between countries. It is therefore essential to create unified surveys including variables that will account for these innovation efforts, innovation and productivity. This is a challenge that should be considered in future studies.

\section{About the Authors}

This article forms part of the project of the "Economical and Social Analysis and Evaluation Network", sponsored by PROMEP-SEP, México. We are grateful with Miguel Angel Mendoza (UNAM) for contributing in methodological suggestions.

Flor Brown is a Professor at the Economics Faculty at the Universidad Nacional Autónoma de México. She was also a visiting Professor at the Universidad Autónoma Metropolitana-Iztapalapa.

Alenka Guzmán is a Professor at the Economics Department and the postgraduate Social Studies program at the Universidad Autónoma Metropolitana-Iztapalapa. 


\section{References}

ACS, Z.J. and Audretsch, D. B. (1988). Innovation in Large and Small Firms: an Empirical Analysis, The American Economic Review,Vol. 78 (4), 678-690.

ALVAREZ, R., Bravo-Ortega, C. and Navarro, L. (20ll). Innovation, R\&D investment and productivity in Chile, Cepal Review, (No. I40), I35-160.

AMEMIYA, T. (1984). Tobit models: A survey, Journal of Econometrics, Vol. 24 (I-2), 3-6I.

ARCHIBUGI, D. and Pianta, M. (1996). Measuring technological change through patents and innovation surveys, Technovation, Vol. 16 (9), 45 I-468.

ARORA, A. (2009). Intellectual property rights and the international transfer of technology:setting out an agenda for empirical research in developing countries, The Economics of Intellectual Property. Geneva:World Intellectual Property Organization.

ARROW, K. J. (1962). Economic Welfare and the Allocation of Resources for Invention, in Groves, H., The Rate and Direction of Inventive Activity: Economic and Social Factors. Princeton: Princeton University Press, 609-626.

ARZA, V. and López, A. (2010). Innovation and Productivity in the Argentine Manufacturing Sector, IDB Working paper series, No. IDB-WP-187, August, 2010.

ASKENAZY, P., Breda, T. and Irac, D. (2010). Advertising and R\&D. Theory and evidence from France, Paris: Paris School of Economics and Paris Jourdan Sciences Economics. WP. No. 2010-45.

BENAVENTE, J. (2006). The role of research and innovation in promoting productivity in Chile, Economics of Innovation and New Technology, No. 15, 30 I-3 I5.

BOYER, R. and Didier, M.. (1998). Innovation et croissance. Paris: Conseil d'Analyse économique, La documentation Française.

BROWN, F. and Dominguez, L. (20I3). La productividad, reto de la industria mexicana. Comercio Exterior, Vol. 63 (3), 1223.

BROWN, F. and Minian, I. (1998). Las redes inter-firma de proveedores innovadores: jestán presentes en la industria de autopartes mexicana? Investigación Económica, Vol. LVIII (224), $9 \mathrm{I}-\mathrm{II} 8$.
CAMERON,A.C., andTrivedi,P.K.(2005).Microeconometrics: Methods and Applications. New York: Cambridge University Press.

CASSONI A. and Ramada, M. (2010). Innovation, R\&D investment and productivity: Uruguayan manufacturing firms, IDB Working paper series, No. IDB-WP- I 9I, August, 2010.

COHEN,W. and Levinthal, D. (1989). Innovation and learning: The two faces of R \& D, The Economic Journal, No. 99, 569596.

CREPON B., Duguet, E., and Mairesse, J. (1998). Research, Innovation and Productivity: An Econometric Analysis at the Firm Level, Economics of Innovation and New Technology, No. 7, II5-158.

CRESPI, G. and Zúñiga, P. (20I2). Innovation and Productivity: Evidence from Six Latin American Countries, World Development, No. 40, 273-290.

DE BONDT, R. (1997). Spillovers and Innovative Activities. International Journal of Industrial Organization, No. 15, I-28.

DUSSEL, E., Galindo, L., and Loria, E. (2003). Condiciones y efectos de la inversión extranjera directa y del proceso de integración regional en México durante los noventa. Una perspectiva macro, meso y micro. Mexico: Plaza y Valdés.

GIRMA, S. A. and Gorg, H. B. (2007). Multinationals Productivity Advantage: Scale or Technology? Economic Inquiry, No. 45, 350-362.

GRILICHES, Z. (1964). Research Expenditures, Education and the Agreggate Production Function.American Economic Review, No. 54, 96I-974.

(1980). Returns to research and development expenditures in the private sector. New developments in productivity measurement and analysis. Conference on Research in Income and Wealth: Studies in Income and Wealth. Chicago: University of Chicago/Press National Bureau of Economic Research.

GRILICHES, Z and Mairesse, J. ( 1984). Productivity and R\&D at the Firm Level. in I.Z. Griliches (editor), R\&D Patents and Productivity. Chicago: Chicago University Press.

GUZMÁN-CHAVEZ, A., López-Herrera, F. and VenegasMartinez, F. (20I2). Un análisis de cointegración entre patentes y crecimiento económico en México, 1980-2008. Investigación Económica, 7I (28I), 83-II5. 
HALL, B. H., Mairesse, J. and Mohnen, P. (20I0). Measuring the Returns to R\&D. in Hall, B.H. and N. Rosenberg (editors), Handbook of the Economics of Innovation. Amsterdam and New York: Elsevier.

HALL, B. H. and Mairesse, J. (20II). Empirical Studies of Innovation in the Knowledge-driven Economy. Economics of Innovation and New Technology, No. I5, 289-299.

HECKMAN, J. (1976). The common structure of statistical models of truncation, sample selection and limited dependent variables and a simple estimator for such models. Annals of Economic and Social Measurement, 5, 475-492.

HECKMAN, J. (1978). Dummy endogenous variables in a simultaneous equation system. Econometrica, 46, 93I-959. Heckman, J. (1979). Sample selection bias as a specification error. Econometrica, 47 (I), |53-6I.

INEGI. (2005). Censos Industriales. Mexico: INEGI.

INEGI. (2003), (2004), (2005). Encuesta Industrial Anual (EIA). Mexico: INEGI.

INEGI. (2005). Encuesta Nacional de Empleo, Salarios, Tecnología y Capacitación (ENESTYC). Mexico: INEGI.

JANZ, N., Lööf, H. and Peters, B. (2004). Innovation and Productivity in German and Swedish Manufacturing Firms: Is there a Common Story? Problems \& perspectives in management, No. 2, 184-204.

JOHNSON, D. K. (2002). Learning by licensing: R\&D and Technology Licensing in Brazilian Invention. Economics of Innovation and New Technology,Vol. I I (3), I63- 177.

KAISER, U. (2002). An empirical test of models explaining research expenditures and research coperation. International Journal of Industrial Organization, No. 20, 747-774.

KAMIEN, M. I. and Schwartz, N.L. (1982). Market Structure and Innovation. Cambridge: Cambridge University Press.

KAMIEN, M. I. and Zang, I. (2000). Meet me halfway: research joint ventures and absorptive capacity. International journal of Industrial Organization, Vol. XVIII (I8), 995-I0I2.

KATRACK, H. (1997). Developing countries' imports of technology, in-house technological capabities and efforts: an analysis of the Indian experience. Journal of Development Economics, No. 53, 67-83.
KUMAR, N. and Aggarwal, A. (2005). Liberalization, outward orientation and in-house R\&D activity of multinational and local firms: A quantitative exploration for Indian manufacturing. Research Policy, No. 34, 44I-460.

LÖÖF, H. and Heshmati, A. (2006). On the Relationship Between Innovation and Performance: a Sensitivity Analysis. Economics of Innovation and New Technology, No. I5, 317 344.

MAIRESSE,J. and Robin,S. (2009). Innovation and productivity: a firm-level analysis for French Manufacturing and Services using CIS3 and CIS4 data (1998-2000 and 2002-2004). Paris: CREST-ENSAE.

MALERBA, F. and Orsenigo, L. (1997). Technological Regimes and Sectoral Patterns of Innovative Activities. Industrial and Corporate Change, 6 (I), 83-117.

MENDONÇA S., Santos Pereira, P. and Godinhod, M. (2004). Trademarks as an indicator of innovation and industrial change. Research Policy, No. 33, I 385-1 404.

MOHNEN P., Mairesse,J.and Dagenais, M.(2006). Innovativity: A comparison across seven European countries. Economics of Innovation and New Technology, No. 15, 39|-4I3.

MONGE-GONZÁLEZ, R., Rodríguez-Álvarez, J., Hewitt, J., Orozco, J. and Ruíz, K. (20I0). Innovation and Employment Growth in Costa Rica. A Firm-Level Analysis. IDB Technical Notes, No. IDB-TN-3 I8.

MULLIGAN, C. B. and Sala-I-Martin, X. (1995). A labourincome-based measure of the value of Human Capital: an application to the States of the United States. NBER WP 5018, Washington: National Bureau of Economic Research.

NAVARRO, J. C., Llisterri, J. J. and Zuniga, P. (20I0). The importance of ideas: Innovation and productivity in Latin America. in C. Pages-Serra (editor), The Age of Productivity: Transforming Economies from the Bottom Up. Washington: Development in the Americas/Inter-American Development Bank/Palgrave-McMillan.

PAKES A. and Griliches, Z. (1984). Patents and R\&D at the Firm Level:A First Look. in Griliches, Z. (editor), R\&D, Patents and Productivity. Chicago: National Bureau of Economic Research, The Universty of Chicago Press, pp. 55-72.

POLDER, M., van Leeuwen, G., Mohnen, P. and Raymond,W. (20I0). Productivity effects of innovation modes. Holland: Statistics Netherlands, The Hague/Heerlen. 
RAFFO, J., Lhuillery, S. and Miotti, L. (2008). Northern and southern innovativity: a comparison across European and Latin American countries. The European Journal of Development Research, No. 20, 219-239.*

ROGERS M., Helmers, C. and Greenhalgh, C. (2007). An analysis of the characteristics of small and medium enterprises that use intellectual property. Manchester College, Oxford University and Oxford Intellectual Property Research Centre, October. Retrieved from: http://www.ipo. go.uk/ipsearch-characteristics-2007/0.

SCHERER, F. M. (2005). Firm size, market structure, opportunity, and the output of patented inventions. in Patents: Economics, Policy and Measurement. Massachusetts: Edward Elgar, pp. I20-I 57.

SOLOW, R. (1957). Technical change and the aggregate production function. The Review of Economics and Statistics, No. 39, 312-320.

THERRIEN, P. and Hanel, P. (2005). Innovation and Productivity: Summary Results for Canadian Manufacturing Establishments. International Productivity Monitor, No. 22, II-28.

VAN LEEUWEN, G. and Klomp, L. (2006). On the contribution of innovation to multi-factor productivity growth. Economics of Innovation and New Technology, Vol. 15 (4), 367-390.

WOOLDRIDGE, J. M. (2010). Econometric Analysis of Cross Section and Panel Data. 2nd edition. Cambridge, MA: MIT Press.

ZÚÑIGA, M. P., Guzmán, A. and Brown, F. (2007). Technology acquisition strategies in the pharmaceutical industry in Mexico. Comparative TT and Society (CTTS), Vol. 5 (3), 274296, December. 